\title{
RICHARD SURFLET, TRANSLATOR AND PRACTITIONER IN PHYSIC
}

\author{
by
}

\author{
M. A. L. COOKE*
}

\section{INTRODUCTION}

RICHARD SURFLET ${ }^{1}$ is remembered for two important translations from French, one medical ${ }^{2}$ and the other on farming, ${ }^{3}$ at the end of the sixteenth century. Very little is known of him, but some interesting glimpses have escaped attention and are worth recording.

Surflet is described as "practitioner in physic" on the title-pages of both his translations." He had claims as an oculist, and the care of the eyes figures

* M. A. L. Cooke, M.A., 18 Dudley Court, Rogers Street, Summertown, Oxford OX2 7LX.

\author{
ABBREVIATIONS USED IN FOOTNOTES \\ BIHR The Borthwick Institute of Historical Research, York. \\ BL The British Library, London. \\ LAO The Lincolnshire Archives Office, Lincoln. \\ NfRO Norfolk Record Office, Norwich. \\ NnRO Northamptonshire Record Office, Northampton. \\ NSDRO The Nottinghamshire Record Office and Southwell Diocesan Record Office, Nottingham. \\ PCC Prerogative Court of Canterbury. \\ PRO Public Record Office, London. \\ RCP Royal College of Physicians. \\ STC Alfred William Pollard and Gilbert Richard Redgrave (editors), $A$ short-title catalogue of books \\ printed in England, Scotland, and Ireland and of English books printed abroad 1475-1640. \\ London, The Bibliographical Society, 1950. \\ STC $^{2} \quad A$ short-title catalogue of books printed in England, Scotland, and Ireland and of English books \\ printed abroad 1475-1640, first compiled by $A . W$. Pollard and G. R. Redgrave. Second edition, \\ revised and enlarged, begun by $W$. A. Jackson and F. S. Ferguson, completed by Katherine $F$. \\ Pantzer, vol. 2, I-Z, London, The Bibliographical Society, 1976.
}

\footnotetext{
${ }^{1}$ The better spelling "Surflet" has been preferred here throughout, except in quotations and references, where variants are retained.

${ }^{2}$ André Du Laurens, $A$ discourse of the preservation of the sight: of melancholike diseases: of rheumes, and of old age. Composed by M. Andreas Laurentius, ordinarie phisition to the King, and publike professor of phisicke in the Universitie of Mompelier. Translated out of French inio English, according to the last edition, by Richard Surphlet, practitioner in phisicke, London, Felix Kingston for Ralph Jacson, 1599 (STC 7304; republished with an Introduction by Sanford Vincent Larkey as Shakespeare Association Facsimile No. 15, London, H. Milford, Oxford University Press, 1938). Kingston printed also in 1599 Thomas Moundeford's Latin translation of the second discourse, De morbis melancholicis tractatus (STC 7303; Larkey, p. viii).

${ }^{3}$ Charles Estienne and Jean Liébault, Maison rustique, or the countrie farme. Compiled in the French tongue by Charles Stevens and John Liebault doctors of physicke. And translated into English by Richard Surflet practitioner in physicke. Also a short collection of the hunting of the hart, wilde bore, hare, foxe, gray, conie; of birds and faulconrie. London, Edmund Bollifant for Bonham Norton, 1600 (STC 10547).

'The two books were both entered at Stationers' Hall in 1598, the Discourse of the preservation of the sight on 1 April, and the Countrie farme on 26 May (Edward Arber, $A$ transcript of the registers of the
} 


\section{A. L. Cooke}

prominentlys in the first book. André Du Laurens's four elegant discourses ${ }^{6}$ had originally been written for a dowager duchess of the French court, whom Du Laurens had treated for cataract, among other things. Surflet's translation is prefaced by several little poems praising his literary labours and medical skill ("Surphlet famous for his art-taught cunning hand, In cleering th'Eyes of spots and noysome Catarrhacts", and "Surphlet ... famous for thy art, In curing of blind catarrhacted eyes") by, among others: Francis Herring, later Censor of the College of Physicians; Gabriel Powell, a theological controversialist; and Ephraim Pagit, another theological writer. Surflet dedicated this publication "To the Right Honorable Sir Thomas West, knight, Lord La Ware, and the right vertuous Ladie Anne his wife", asking them to accept the book "not so much in respect of any your present infirmities that I am privie unto, as to make way for the shutting out of such as hereafter might creepe upon you to your untimely annoyance". Perhaps he had attended them professionally.

The second translation, the Countrie farme (1600), was a massive compendium of agricultural, horticultural, and veterinary information, theories and superstitions. It was one of the most influential Renaissance books dedicated to the improvement of farming methods. The French original, ${ }^{7}$ enlarged from the Latin Praedium rusticum (1554) of Charles Estienne (d. 1564), the physician son of the great family of humanist printers and scholars, was compiled and written by his son-in-law, Jean Liébault (d. 1596), a physician also. Medicine had strong affinities with rural things, in a predominantly agricultural world relying much on herbal remedies. Five chapters are devoted to "phisicke herbes", in addition to many passing recipes for herbal medicines. A long chapter deals with the husbandman's illnesses, really a general medical compendium: "The remedies which a good huswife must be acquainted withall, for to helpe her people when they be sicke". ${ }^{9}$ Rural affinities also explain the interest of these three physicians in veterinary medicine. The volume, in both its French and English versions, has at the end a "table of the diseases and remedies described", in which human and animal maladies are listed together without distinction. ${ }^{10}$ The Countrie farme was republished in $1606^{11}$ and 1616 . The first two

Company of Stationers of London, 1554-1640 A.D., London, privately printed, 1876, vol. 3, pp. 109 and 116).

${ }^{3}$ Seventy-one out of 194 pages. On the first discourse, Surflet's text is used in: Percy Dunn, 'A sixteenthcentury oculist', Proc. R. Soc. Med., Sect. Hist. Med., 1916, 9: 120-142, about Du Laurens.

- Discours de la conservation de la veuë: des maladies melancholiques: des catarrhes: \& de la vieillesse. Composé par M. André du Laurens, Medecin ordinaire du Roy, \& Professeur de sa Majesté en l'Université de Medecine à Montpellier. Reveus de nouveau \& augmentez de plusieurs chapitres, [s.l.], pour Theodore Samson, 1598 (3rd ed.).

${ }^{7} L$ 'agriculture et maison rustique, de MM. Charles Estienne, et Jean Liebault, docteurs en medecine. Edition derniere. Reveüe \& augmentee de beaucoup ... Plus un bref recueil des chasses du cerf, du sanglier, du lievre, du renard, du blereau, du connil, du loup, des oiseaux, et de la fauconnerie, Lyons, Jacques Roussin, 1594. Surflet omits, no doubt deliberately, the section on the wolf, by Jean de Clamorgant.

Op. cit., note 3 above, pp. 254-300.

Ibid., pp. 53-86.

${ }^{10}$ On a minor veterinary aspect (working dogs) of the book: J. W. Barber-Lomax, 'The Countrey farme', J. small Anim. Pract., 1961, 2: 202-205.

11 The 1606 edition (STC 10548) was printed by Arnold Hatfield for John Norton and John Bill, the title being unchanged except for a few spellings. 


\section{Richard Surflet, translator and practitioner in physic}

editions were dedicated to Lord Willoughby of Eresby (Peregrine Bertie), who in fact died in 1601. After Surflet's death, the 1616 edition, revised and enlarged by Gervase Markham, ${ }^{12}$ the prolific agricultural and veterinary writer and compiler, was dedicated by Markham to Robert Bertie, the next Baron. Markham did not attempt to pass Surflet's work off as his own. Acknowledging the hand of "a learned and well experienced Gentleman, who in the translation, tooke a long and well-meriting labour", he preferred to emphasize his own improvements to Surflet's text.

Surflet had matriculated at Cambridge at Michaelmas 1576 as a sizar at Trinity College but did not graduate. ${ }^{13} \mathrm{He}$ was probably born about $1560-1563$, if he entered Trinity College at the usual age for that time. It has been suggested that he settled at King's Lynn, ${ }^{14}$ since Richard Banister, the able oculist and nephew of the surgeon John Banister, learnt some of his craft from a Master Surflet of Lynne:13 "When in the threshold of my practice I could couch the Cataract, and so began to gaine some name of an Oculist, I laboured to advance my skill by the advice of the most skilfull in those times: as namely, Henry Blackborne, famous for the forenamed cures, my kinde acquaintance Robert Hall of Worcester, Master Velder of Fennie-Stanton, Master Surflet of Lynne, and Master Barnabie of Peter-borough, all excelling in these operations". ${ }^{16}$ As shown in the Appendix below, this Master Surflet of Lynn was, in fact, not Richard Surflet, though both were known for their treatment of eye maladies.

\section{RICHARD SURFLET'S WILL}

Richard Surflet's interesting will, made in contemplation of a voyage on which he died, has been only briefly considered ${ }^{17}$ and is here transcribed from the register copy in the Public Record Office, London. ${ }^{18}$

${ }^{12}$ Maison rustique, or, the country farme compyled in the French tongue by Charles Stevens, and John Liebault, doctors of physicke. And translated into English by Richard Surflet, practitioner in physicke. Now newly reviewed, corrected, and augmented, with divers large additions, out of the works of Serres his agriculture, Vinet his Maison Champestre, French, Albyterio in Spanish, Grilli in Italian; and other authors. And the husbandrie of France, Italie, and Spaine, reconciled and made to agree with ours here in England: by Gervase Markham, London, Adam Islip for John Bill, 1616 (STC 10549). "His additions are numerous”' (Frederick Noël Lawrence Poynter, ‘A bibliography of Gervase Markham 1568?-1637', Oxford Bibliographical Society Publications, 1962, new series, 11: pp. 27, 115, 148-150).

${ }^{13}$ John Venn and John Archibald Venn, Alumni Cantabrigienses, Cambridge University Press, 1927, part I, vol. 4, p. 185. Of the 67 admissions to the college in that year, 35 graduated, 32 did not. Of the latter, 15 were sizars (Walter William Rouse Ball and John Archibald Venn, Admissions to Trinity College, London, Macmillan, 1913, vol. 2, pp. 107-111).

${ }^{14}$ Larkey, op. cit., note 2 above, p. ix. Arnold Sorsby, 'Richard Banister and the beginnings of English ophthalmology', in Edgar Ashworth Underwood (editor), Science, medicine and history. Essays in honour of Charles Singer, London, Oxford University Press, 1953, vol. 2, pp. 42-55, see p. 53.

is Robert Rutson James, 'Mr. Surphlete, an item of ophthalmological history', Br. J. Ophthal., 1947, 31 : 3-8. See also note 14 above.

${ }^{16}$ Richard Banister, preface "To the Reader", in: [Jacques Guillemeau.] A treatise of one hundred and thirteene diseases of the eyes and eye-liddes [with Banister's Breviary of the eyes], London, Felix Kyngston for Thomas Man, 1622 (STC 1362), fol. A 6r. On Guillemeau's translator, see section 4 and note 73 below. On Kingston, cf. notes 2, 28 and 36.

17 James, op. cit., note 15 above, includes a number of errors and omissions.

10 PRO, PCC wills, Stafford 43, Prob.11/107, fol.346 $-347^{v}$. There is also the copy filed by the executor, Prob.10/241. In the date of the will, 1603 means the modern 1604, since the year began on 25 March. 


\section{A. L. Cooke}

\section{T[estamentum] Richardi Surflete}

AS I CAME FROM THE EARTH the common mother of all mankynde: soe I knowe I shall retorne unto the same againe, and with others the workes of God be resolved into my first matter. And seeinge the time as a thinge moste uncertaine is unknowne unto me but nowe uppon this goinge to Sea more probablye approachinge by reason of the longe and daungerous occurrences dependinge thereon I thoughte it my parte to set my thinges in order that soe (if God doe call me hence) I maye be the freer to wayne myself from worldly and transitorie thinges and to have my mynde onely intente uppon those wherein true felicity is placed. And first I bequeath myself sowle and bodye to that most lovinge and mercifull god who hath given his sonne Jesus Christe borne of a woman to suffer death uppon the crosse for me and all the elect, nott doubting but that as he hath nombred my dayes and is of all sufficient power to restore me agayne in health and safetie to my Native soyle (if soe it seeme good to him in his infinite wisdome) soe he will after my dissolucion (whether by lande or Sea) receave me for the same his Christes sake into eternall blisse forgiveinge me all my synnes orriginall and actuall, and imputinge unto me the full and perfect obedience of his deare and onely begotten sonne whereby I shall stande unspotted and blameles before his throane of Justice, never to be called into Judgmente but to passe from death to life. As for the goodes which god of his mercie hath blessed me with all my desire is That they be all sould and turned into money. Of this money I give to William Bingham a Carver dwelling in Gleave Alley in Southwark thre pounde six shillinges eight pence. To maister Travers and master Egerton Twentie shillinges a peece. To maister Bandforde and $\mathrm{mr}$ Paget of Detford tenne shillinges a peece. To $\mathrm{mr}$ Crosley whom I make Supervisor for the discharginge of this my wyll and to receive whatsoever moneys may any manner of way be due unto me the somme of fiftie three shillinges and fower pence. To his wiefe tenne shillinges And to every one of his daughters six shillinges eight pence. The Rest of all such moneys as shall remaine I desire to be layed out in some lease as may be most proffitable either in the Cittie or Countrey And the yearelye revenue growinge thereof for the space of every six yeres to be bestowed in the placinge and stockinge of some one of the sonnes of Richard Surfleet John Surflete or Robert Surflete suche as shall be of most hope for godlines and towardlines with some Religious and honest man in some good and commendable Trade But the Revenue of the seaventh yeare I desire to be bestowed uppon the godly distressed and afflicted and this by mutuall intercourse to be contynued from seaven yeres to seaven yeares to the full expiracion of such lease of twenty one yeres. And if it should please god to call maister Crosley away by death before such time expired Then my desire is that he would commende these partes and Offices to be performed by some other honest frende of his fearinge god, or else to gett master Travers or master Egerton or some other faithfull Minister such as shall then be of good reporte like unto them here in the Citty to procure one to doe the same. to which my last wyll and Testament made the firste of March One thouzand six hundred and three I putt my hande and seale in the presence of us Hugh Evans, William Tilney, William Shambroke, Abraham Webbe By me Richard Surfleete.

Left in the Cyttie,

AN INVENTORY of such goodes as I carrie with me to the Sea or otherwise leave with my frendes in London made the day and yeare within wrytten. Imprimis one great vessell of bookes at Maister Theralde the Lynnen Draper his house in Fryday street at the signe of the maydens head and Unicorne, and in the same place one old hampear with nothing but trash. Item at maister Crosley his house at the Goulden lyon at the Stockes one hamper and in it a clock called an Alarum, a great box with Surgery instrumentes, a lesser box called a playster box with surgery instrumentes, also some of silver and some of iron, a box with my letters of orders, a license to practise Phisique, my clocke plummettes and a canvas bag with sundry sortes of thinges in it. Item one rapyer and a dagger, a grograine gowne with a velvet face cape and garding, a velvet jerkin, a satten doublet, two stuff doubletes, two paire of rounde cloth hose, one paire of hose of velvet panes and cannyons, one paire of new Jersie stockinges of fouretene shillinges pryce, one peece of Dornix with curtaine ringes at it, one ball of velvet garding, one new cloake faced with velvet, one rydinge cloake and an olde paire of baces, one paire of bootes and spurres, one cloth sadle with thre girthes, a petterell and crupper, one bridle with bytt and bosses, six ruff bandes of cambrick, one newe hatt faced with velvet, one course sheete to wrap my apparrell in, one velvet muff, one velvet cape for a cloake uppon cloth.

TAKEN WITH ME TO SEA First one Truncke, one mayle, thre boxes with lockes whereof one is made deskwyse, two gownes, the one of stuff, the other of cloth, one cloake faced with velvet, one hat, one Dutch cap, one silcke quilted cap, one other cap of sparta velvet, two fustian nightcappes, seaven lynnen cappes, whereof one is a lytle wrought with black silck in a border aboute the edges, and three of the other are newe, five dozen and a haulf of falling bandes, two dozen new hande towels, and as many table napkins, handkerchers two dozen and a haulf, cuffes thre newe paire with black and white edging 


\section{Richard Surflet, translator and practitioner in physic}

lace and many payres of old ones, two doubletes of stuff, fower jerkins, one of silck, an other of cloth, the Two other of stuff, one newe, the other old, two crane feathered fustian mandillions, two paire of drawinge breeches of the same, fower paire of cloth breeches, two trusses of canvas, six paire of lynnen breeches, six fustian wastcoates, eightene new shirtes and six old, thre paire of oiled leather lyninges, five payre of lynnen stockinges whereof fower are newe, one paire of wosted stockinges black and newe, two paire of jersy but old, a fowerth paire of woollen yarne newe, a fifte paire of russet cloth, And a sixte of white knytt ones very thick and hayrie bought at Cracovia by a Transilvanian Embassadour, new shoes three paire, old shoes two paire, one paire of pumppes and pantofles olde, a new paire of slippers, an old paire of lyned moyles but lytle or nothing worne, one paire of newe pennystone blanckettes, three newe paire of hose garters, two of crewell and one of silck, one bedrugge newe, one woolbed and two pillowes, two fustian pillowbeeres new, one mat, one brush for clothes, one headbrushe, a lookinge glasse, two combes of box in cases, a paire of snuffers, an extinguisher, A wooden standish with penknife \&c A fayre Inckhorne with a penner and sandbox two and of the same, fower newe paire of gloves, an old motley clokebagge, bookes a hundred and eight or thereaboute and of name as followeth: one hebrew bible, one Tremelius in fol., one English bible guylded and prynted at Geneva, a French bible, one Greeke Testament, one French testament, Calvine on Deutronomy and Job, Calvine uppon the psalmes in latin, one Institucion and epistles, Beza his epistles and confessions, Du Plessy against the Masse, Grineus workes, Parkins workes fol., Daneus on the Lordes prayer, his Ethick and Isagoge Christiana in 2 vol., one Polani Theses and Theses Gen[ev]enses, one Perkins problem, his booke de predestinatione, his prophetica and Specimen Degesti, one Ursinus Catechisme, Sculteti medulla patrum, Flores Doctorum, one smale Tablebooke, the drumm of doomesday, Knewstubbs on the commaundementes, Dearinges lectures, Virels dialogues, Bakers lectures on the Creede, the harmony of confessions, Fenners Theologie, the Councell of Trent, one Perkins of sathans sophistry, Hunters Cosmographie, one sermon of repentaunce, six smale Cathechismes, the goulden booke of the leaden godes, Brocard on the Cantacles, Finch his divinytie, one treatise of fastinge set forth in Scotlande, one Immytacion of Christ, one forme of common prayer, one Monomachie of motives, Cartwrightes litle Catechisme wrytten, one other booke of the forme of common prayer \&c., one other Cathech [isme] with the text of the Quotations, Stephanus his concordans, Fenners houshold discipline, one destruction of smale vices, one other smale Cathechisme, Fernelius his workes fol., Piso his methodus \&c., Valverda his Anatomicall tables, Banasters anathomy, Weckers spetiall Antidotari, Parry his Surgery, Schenkius his observacions in 2 vol., Penotus de vera preparatione medicamentorum Chymicorum, The cure of diseases in remote Regions, Gratias ab Horto of East Indian simples, Laurentius de Cresibus, Clowes his practise of Surgery, Botallus de missione sanguinis, Willichius de Urinarum probationibus, Weckers surgery in English, Ronseus de magnis Hipp[ocratis] lienibus, one great lexicon, one Thom[asius] dictionary, one dictionarium poeticum, Martinus Gramer, Paginus Epitome, Scotus greeke gramer, Mathiolus of the facultyes of simples Decimo sexto, one Taleus Rethorick, Cartwrightes Treatise of fastinge, Phregio his questions, Macropedius de Conscribendis Epist[olis], Phregius his pedagogus, one Licosthenes Apothegmes, Aristotles Sentences, Tullyes sentences, Flores poetarum, The smale Greek Poetes, Verons phisickes, Dodoneus his Cosmographie, Bright uppon Scribonius phisickes, Daneus his phisickes, Ovides Metamorphesis, thre smale paper bookes, Bourne his Regiment for the sea, one bounde paper booke conteyning fower quires of wryting paper, one booke of cap paper conteyning one quire, 1 folio paper booke conteyning one Epitome of $\mathrm{Mr}$ Cartwright uppon the commaundementes And twentie pounde in Spanish Ryalles.

VICESIMO SEXTO die mensis Junii Anno Domini millesimo Sexcentesimo sexto emanavit commissio Willi[el]mo Crosley Supervisori nominato in Testamento dicti defuncti ad administrand[a] bona Jura et credita dicti def[uncti] juxta tenorem Test[ament]i h[ujus]mo[d]i (eo quod dictus defunct[us] nullum in dicto suo Test[ament]o nominavit Executorem) de bene et fidel[ite]r administrando eadem Ad sancta dei evangelia Jurat.

The Act Book ${ }^{19}$ of the court granting the commission to administer supplies the additional information that Richard Surflet, the testator, was late in parts beyond the seas ("nuper in partibus ultramarinis") and died there ("dec[essit] in partibus").

The opening is unusual and distinctive. Instead of the formula "In the name of God, Amen", Richard Surflet's first reference is to the Earth, the common mother of mankind. The position of honour which he accords to her at the head of his will is

19 PRO, PCC act book Prob.8/13, p. 73. 


\section{A. L. Cooke}

deliberate. In his dedication of the Countrie farme to Lord Willoughby, he had revealed a curiously religious, almost pagan reverence for the Earth, "this laboured worke, the magazin and store-house of all such knowledge, as may make for the honour, dignitie, maintenance, and beautie of that common mother; from whose wombe we (even all of us) are not onely descended; but by whom wee are still sustained; and into whose bosome death shall no sooner cast us, than we shall be welcome, lovingly received, throughly and indistinctly reunited, and safely reserved until the great day of summons, whereupon she will as readilie render and repaie whatsoever hath beene thus committed to her custodie and charge". ${ }^{20}$ This echoes the ancient pagan theme in the book itself, where the authors say of the earth: "it beareth all manner of corne, fruits, hearbes, timber trees, mettals, stones and other thinges, and this hath beene given unto it even since it was first made, and heereupon olde writers have justly given unto it the due name of mother". ${ }^{21}$ Surflet even speaks of the earth as "so divine a substance", yet he does not go so far as identifying it with the Creator in a thorough-going pantheism: "You shall cleerely see that there cannot too reverend an estimation be had of the earth; and that it is to faile and come short of the scope of the Creatour ... to account thereof in any base and vile manner". ${ }^{22}$ At the great day of summons, the earth will deliver his body up again for the last judgment, where he will be among God's elect (his will speaks of Christ's death upon the cross "for me and all the elect"). In all this, his devotion to the earth, the common mother of mankind, stands out at the head of his will as the clearest possible signature of the translator of the Countrie farme.

In most of his attitudes and ideas, Surflet professed a narrow, conventional puritanism, which accompanied an uncharitable character, as, for example, in his Knoxian attack on women in the introduction to the Countrie farme, with its joyless puritanism: "I could wish all such of that sexe as are religious, to looke before they leape, and to be wise according to sobrietie and gravitie: Sobrietie, not medling above their place and reach, in matters of Phisicke: and gravitie, as not having anything to doe in the matter of Fukes, either for using or preparing of them; seeing they argue, if not plainely proove, a light, a loose, and verie sinfull life". ${ }^{23}$ In the British Library copy of the 1600 edition, someone wrote many years ago on the title-page: "Simulata sanctitas duplex iniquitas". Was it a reference to Surflet?24 The principal bequest of Surflet's will, made in London, placed upon his executor ${ }^{25}$ the burden of passing judgment upon certain of the testator's young relatives, in order to reward the most godly

\footnotetext{
${ }^{20}(1600)$ fol. a $1^{v}$.

21 Ibid., p. 13.

22 Ibid., fol. a $1^{r}$.

${ }^{23}$ Ibid., fol. a $3^{\text {r }}$. Fukes were "paint or cosmetic for beautifying the skin", e.g.: "Compound waters are of three sorts, some are for phisicke, othersome for sweetenes, and the other for fukes and painting, as ornaments to the body" (ibid., p. 592; James A. H. Murray (editor), A new English dictionary on historical principles, Oxford, Clarendon Press, 1901, vol. 4, part 1, p. 582). On women in medicine, cf. Banister's Breviary (note 16 above), fol. a $7^{r}-a 9^{r}$, Sorsby, op. cit., note 14 above, p. 48.

24 The note is followed by the name or signature "N. Ringros".

${ }^{2 s}$ William Crosley, a grocer in the parish of St Mary Woolchurch (d. 1610). Strictly, he was appointed "administrator with will annexed", by the court, since the will constituted him supervisor only and omitted to name an executor.
} 


\section{Richard Surflet, translator and practitioner in physic}

and diligent. His task was to invest the residuary funds in a lease, for twenty-one years, and to apply the income of all except the seventh, fourteenth, and last years towards "the placinge and stockinge of some one of the sonnes of Richard Surfleete, John Surflete, or Robert Surflete, such as shall be of most hope for godlines and towardlines with some Religious and honest man in some good and commendable Trade". The income from each seventh year was to be "bestowed uppon the godly distressed and afflicted".

For some reason, Surflet made an inventory, appended to his will, of the principal things, mainly clothes and books, which he took with him on his important voyage. Perhaps he thought that it might assist in their recovery if he failed to return alive. The books which he left behind are not given in detail, but the many volumes which he took to sea are individually listed, mostly works on theology and medicine, with a few classical authors. It is not always possible to identify the edition. ${ }^{26}$ One cannot fail to notice the Genevan bias of the theological literature. His learning included works in Latin, French, and Greek, even a Hebrew bible (he had quoted briefly from it - a minor typographical adventure - in his dedication to Lord Willoughby).

Prominent among Surflet's authors is Thomas Cartwright, "the head and mo." learned of that sect of dissenters then called puritans", ${ }^{27}$ who had died the previous year, 1603. Some of his works circulated in manuscript among his followers before they were printed, and this seems to have applied here to the catechism referred to as "wrytten". ${ }^{28}$ Cartwright had been a fellow of Trinity College. Among those with whom he was most involved in his stormy career of theological controversy and polemic was Walter Travers, another leading puritan divine from Cambridge, ${ }^{29}$ and also mentioned in Surflet's will. Cartwright and Travers corresponded much with one another, and their works and careers were to a large extent interlinked. ${ }^{30}$ Like Cartwright, who succeeded him as English minister at Antwerp, Travers spent much of his life abroad on account of his extreme opinions. In old age, he had come home, like Cartwright. He appears, as "maister Travers", together with Stephen Egerton ("master Egerton"), another prominent puritan, ${ }^{31}$ twice in Surflet's will, both receiving twenty shillings. Since 1598, Egerton had been minister at St Anne's, Blackfriars, and in the first years of the new reign emerged as "London leader of the militant puritan ministry".32 "Mr Paget of Detford", also named, was probably Eusebius Pagit, ${ }^{33}$ another of the puritans and father of the Ephraim Pagit who wrote one of the

\footnotetext{
${ }^{26}$ A bibliographical study has not been attempted here. Among the medical books was another by $\mathrm{Du}$ Laurens, De crisibus libri tres, probably the 1596 edition from Frankfurt.

${ }^{27}$ John Strype, quoted in Dictionary of national biography, London, Smith Elder, 1908, vol. 3, p. 1135.

${ }^{28}$ This was perhaps Cartwright's catechism issed in 1616 by the same printer and publisher as Richard Banister's book (note 16 above). Entitled The doctrine of Christian religion, contracted into a short catechisme, it was appended to Cartwright's $A$ treatise of Christian religion (not in STC), pp. 361-376.

29 Samuel James Knox, Walter Travers: paragon of Elizabethan puritanism, London, Methuen, 1962. Patrick Collinson, The Elizabethan puritan movement, London, Jonathan Cape, 1967, pp. 107-108, 110, $128,153,234,238,269,271,294-296,303,320,388,412,455$.

30 "Allowing Mr Cartwright for the Head, Mr Walter Travers might be termed the neck of the presbyterian party" (Thomas Fuller, quoted by Knox, op. cit., note 29 above, p. 11).

${ }^{31}$ Collinson, op. cit., note 29 above, pp. 320-321, 341, 449, 452.

32 Ibid., p. 446.

${ }^{33}$ Ibid., pp. 143, 151, 193, 276, 368, 370.
} 


\section{A. L. Cooke}

poems prefacing Surflet's 1599 translation. At the time when Surflet set out on his voyage, Travers and Egerton had been lately much involved in the turmoil surrounding the long-awaited conference which took place at Hampton Court in January 1604, followed quickly by Archbishop Whitgift's death. At Hampton Court, the dwindling hopes of the surviving Elizabethan puritans for the further reformation of the Church of England were finally dashed. There was an atmosphere of disappointment and disillusionment: it was the end of an era, "the last chapter in the history of the Elizabethan puritans" ${ }^{34}$ Perhaps the despair at the failure of the puritan cause was among the factors, unknown today, which influenced Surflet's decision to go on his long sea voyage.

\section{THE VOYAGE}

Richard Surflet died "in parts beyond the seas", ${ }^{35}$ and his will was clearly made in contemplation of a major voyage, with "longe and daungerous occurrences depending thereon". Among his books at sea, five stand out in signficant contrast to the main run of his theological and medical books and provide a clue to the nature of the voyage: "Hunters Cosmographie ..., the Cure of diseases in remote Regions, Gracias ab horto of East Indian Simples ..., Dodoneus his Cosmographie ..., Bourne his Regiment for the Sea". ${ }^{36}$ That he took Spanish money with him, far from suggesting that he was going "possibly to Spain", ${ }^{15}$ reinforces the impression that his goal was much farther across the seas, for Spanish money was the principal international currency, exactly what he would need for a major voyage..$^{37}$ One cannot say, in the face of these indications and the plain language of the will, that Surflet "was simply going abroad". ${ }^{15}$ The whole tenor of the will is of a man planning an ambitious and hazardous ocean voyage to a savage, remote, and little-known land, and the mention of the East Indies provides an immediate clue, which can be followed up in the contemporary travel accounts. Our testator is named there as the preacher and physician on board Captain (later Sir) Henry Middleton's ship on the recently formed East India Company's second expedition to the East Indies, under Middleton's command..$^{38}$ For this, Bourne's navigational volume was even more appropriate than

\footnotetext{
${ }^{34}$ Ibid., p. 447.

${ }^{33}$ The exact date of death is not given.

${ }^{36}$ One may perhaps identify the following editions: Johann Honterus, Rudimentorum cosmographicorum libri iii, a late edition such as Prague 1595; G[eorge] W[ateson], The cures of the diseased in remote regions, London F[elix] K[ingston] for $\mathrm{H}$ [umfrey] L[ownes], 1598 (STC2 25106 and 25106a); Garcia de Orta [otherwise ab Horto], Aromatum et simplicium aliquot medicamentorum apud Indos nascentium historia (translated from the Portuguese and edited by Charles de L'Ecluse), Antwerp, Plantin-Moretus, 1593 (a late edition); Rembert Dodoens, De sphaera sive de astronomiae et geographiae principiis cosmographica isagoge, Antwerp, Plantin, 1584; William Bourne, A regiment for the sea, probably the edition of 1592 (STC 3427) or 1596 (STC 3428), both London, T. Est or Este for T. Wight.

${ }^{37}$ It was, in fact, used in Bantam, where Surflet went (Edmund Scott, An exact discourse of the subtilties, fashions, pollicies, religion, and ceremonies of the East Indians, London, W.W. for Walter Burre, 1606 (STC2 22061), e.g. fol. D 3r-E $1^{v}$ ).

${ }^{38}$ The last East-Indian voyage containing much varietie of the state of the severall kingdomes where they have traded: with the letters of three severall kings to the Kings Majestie of England begun by one of the voyage; since continued out of the faithfull observations of them that are come home, London, T.P. for Walter Burre, 1606 (STC2 17869). Reprinted in Sir William Foster (editor), The voyage of Sir Henry Middleton to the Molluccas, 1604-1606, Publications of the Hakluyt Society, second series, no. 88, London, 1943, see p. xvii. Still useful is: Bolton Corney (editor), The voyage of Sir Henry Middleton to
} 


\section{Richard Surflet, translator and practitioner in physic}

at first apparent, since it contained a detailed "hidrographicall discourse" of five routes to the East (albeit partly theoretical, including one over the North Pole), "to shew the passage unto Cattay ... and also the rest of the East Indies".

The expedition was off the Lizard by 2 April 1604, having sailed from Gravesend on 25 March. Surflet made his will on the first of that month. ${ }^{18}$ Four ships sailed. At Bantam, after a long and arduous outward passage, two, the Hector and the Susan, were, in accordance with the Company's instructions, loaded with a cargo mainly of pepper and sent home in February 1605, while Middleton proceeded farther east with his own Red Dragon and the Ascension, taking in cargoes of cloves. The Susan was lost on the return voyage. The Hector managed to survive, but most of her crew perished; she was found by Middleton on his return passage, off the Cape of Good Hope and in a sorry state. The three ships, with the survivors of the expedition, then proceeded homewards together, reaching the Downs on 6 May 1606, where they "rid eight dayes for a faire wind". The expedition, though financially profitable, had suffered grievously from dysentery, following on scurvy, and many lives were lost. ${ }^{35}$ Surflet's will was proved on 26 June 1606, i.e. a few weeks after the expedition's return. This is just the sort of interval that one would expect for confirmation of the death to reach the executor and for the fulfilment of the necessary formalities for probate.

On the outward journey, many of the crew of Middleton's ship were already sick by the time the equator was crossed, and the account goes on to criticize Surflet's attitude and incompetence: "the 16. of May [1604] wee passed the line, where many of our men fell sicke of the Scurvy, Calenture, Bloudy flix, and the Wormes, being left to the mercie of God, and a smale quantitie of Lyman juyce every morning: our physition shipt for that purpose being as unwilling as ignorant in anything that might helpe them. A great oversight in the company, and no doubt wilbe better lookt to hereafter". ${ }^{40}$ The narrator gives no further comment on Surflet's conduct or treatment at this point.

The value of lemon and orange juice against scurvy was observed and tested as early as 1593 by Sir Richard Hawkins: "This is a wonderfull secret of the power and wisedome of God, that hath hidden so great and unknowne vertue in this fruit";41 although it was not until 1795 that its use became general on the Navy's ships. On the Company's 1600 expedition under Captain James Lancaster, the men on his ship, who had lemon juice, had been protected from scurvy, whilst those on the other ships, lacking it, fell grievously ill. The Company learned from this. Middleton "had already

\footnotetext{
Bantam and the Maluco Islands; being the second voyage set forth by the Governor and Company of Merchants in London trading into the East-Indies. From the edition of 1606, Publications of the Hakluyt Society, no. 19, London, 1855. The Company received its charter from Elizabeth in 1600.

${ }^{39}$ Edward Heawood, $A$ history of geographical discovery in the seventeenth and eighteenth centuries, Cambridge University Press, 1912, pp. 54-55. Samuel Purchas, Hakluytus posthumus; or, Purchas his pilgrimes (1625, STC ${ }^{2}$ 20509), Glasgow, James MacLehose, 1905-07, vol. 2, pp. 478-481, 490, 496-502. Frederick Charles Danvers, Letters received by the East India Company from its servants in the East, London, Sampson Low, 1896, pp. xxvi-xxviii.

${ }^{40}$ Op. cit., note 38 above (1606), fol. B 3r; (1943), p. 9.

41 'The observations of Sir Richard Hawkins, knight, in his voyage unto the South sea. An. Dom. 1593' (1622, STC 12962), in Purchas, op. cit., note 39 above, vol. 17, pp. 57-199, see pp. 78 and 90 . Donald McDonald, 'Dr John Woodall and his treatment of the scurvy'. Trans. R. Soc. Trop. Med. Hyg., 1954, 48: 360-365: p. 360.
} 


\section{A. L. Cooke}

played an active part in the Company's first voyage", ${ }^{42}$ and it is plain that lemon juice was now used on his ship, though the ration was inadequate. "In view of Lancaster's experience of the usefulness of lemon-juice as a preventive, a small quantity had been brought out, but it was quite insufficient." ${ }^{43}$ Surflet's views on the use of the lemon juice are not recorded. Its mention in the account is another indication that the value of citrus fruit against scurvy was becoming known before the important advice of John Woodall, the Company's Surgeon General, in 1617. By that time, Woodall himself says that "some surgeons" on ships were giving the juice daily as a prophylactic. His advice that it be reserved for treatment was followed on the Company's ships: "there is a good quantity of Juice of Lemmons sent in each ship out of England in the great care of the Marchants, and intended onely for the releefe of every poore man in his neede". ${ }^{44}$ A modern writer comments: "The supply had evidently by that time become a regular issue to all ships of the Company".45

Later in the year (1604), Middleton's crew became increasingly ill with scurvy. Surflet is again criticized, but had died since: "here began the scurvy to grow amongst our men, and every day did the disease encrease. Here might some what be said of the ignorance and uncharitablenes of him that was shipt for our physition, as a caveat to them that shall go hereafter to be better provided: but for 2 . respects I forbear, the one in regard of his other calling, but chiefly for that he is since dead in the voyage; where for my part I wish his faults may be buried with him". ${ }^{46}$ At Bantam, early in 1605, he had been transferred to the ill-fated Hector and sent home: on 16 January, Middleton "departed from Bantam, and came a bord to proceed on his voyage to the Mollocos, ... also the same day maister Surfflict was appointed to go home in the Hector, to the great contenting of all in our ship...."47 On her return voyage, some fifty-three men (all but ten) perished..$^{48}$

For better or worse, Surflet's faults were indeed buried with him: there is no detail of how or why he was considered unwilling and ignorant. The charge of ignorance is particularly interesting at a period when so little of real value was known anyway. Could there have been a dispute as to the use of the vital lemon juice? Surflet himself had been stern in his denunciation of quacks, "the painted crew of seeming Phisitions and pratling practisers bothe men and women, gathering their skill, honestie and most precious secrets, from the rich mines of brasen-faced impudencie and bold blindness", admonishing his reader, "as thou tenderest thy health and wealth, to avoide such noisome vermine and deepe deceivers". ${ }^{49}$ The charge of unwillingness is also odd. In spite of his uncompromising puritan outlook, he clearly set out with the intention of

${ }^{42}$ Op. cit., note 38 above (1943), p. xv.

${ }^{43}$ Ibid., p. xviii $n$.

4 John Woodall, The surgions mate, London, E. Griffen for L. Lisle, 1617 (STC22 25962), pp. 184-185. McDonald, op. cit., note 41 above, p. 361. John Joyce Keevil, Medicine and the Navy, Edinburgh, E. \& S.

Livingstone, 1957-58, vol. 1, p. 220.

is McDonald, loc. cit., note 44 above.

${ }^{46}$ Op. cit., note 38 above (1606), fol. C $3^{\text {r }}$; (1943), p. 15.

${ }^{47}$ Op. cit., note 38 above, (1606) fol. C $4^{r}-C 4^{v} ;(1943)$, pp. 17-18, 150. "Also he left Maister Surflyt the Docter of Physick and preacher, to goe home in the Hector" (Scott, op. cit., note 37 above, fol. K $3^{\mathrm{r}}$ ).

48 Op. cit., note 38 above (1855), p. 77.

49 discourse of the preservation of the sight, note 2 above, fol. A $3^{\text {r }}$. 


\section{Richard Surflet, translator and practitioner in physic}

being a diligent ship's physician. What went wrong? The third charge, uncharitableness, is more recognizable: we have seen that he was smug and severe in his condemnation of others. It must be his lack of realistic compassion, above all, which made him disliked. He probably, as a religious zealot, lacked the worldly wisdom, the esprit de finesse, the artfulness even, to gain and command the respect of his patients. Also, in spite of his reverential views on the earth and the country, the long list of clothes in his will suggests a fastidious and potentially squeamish character who would have been out of place in arduous conditions. From the professional angle, it is only fair to add that, when the Company's first fleet (the same four ships) had previously sailed for the East in December 1600, "to each ship were appointed 'Surgeons twoe and a Barber"'so whilst Surflet appears to have been single-handed on the Red Dragon, as both preacher and physician.

There are references to his qualifications in his will, which show that he was indeed both in holy orders and a licensed practitioner in physic. Among the chattels which he left in London were surgical instruments, "a box with my letters of orders", and "a license to practise Phisique". It was by no means unknown for educated clergymen to practise medicine. Surflet was referred to by Edmund Scott at Bantam as "the Doctor of Physick and preacher", ${ }^{47}$ although this need not mean he had a doctorate. In 1587, he had been called before the College of Physicians, apparently for practising without a licence. He denied that he had practised medicine and confessed that he had no degree, although he had been at Trinity College, Cambridge, for two years. No decision was taken, and he was not brought before the College of Physicians again. ${ }^{51}$ The licence was therefore obtained between 1587 and 1599, when the first book calls him practitioner in physic. But his references to instruments suggest that he had also practised surgery, and he had three surgical books with him, including John Banister's translation of Wecker..$^{32}$

Among his medical books on the Red Dragon was also John Banister's "Anathomy". ${ }^{33}$ Surflet was, in one way, following in Banister's footsteps: Banister had himself sailed for the East Indies, in 1582-83, in the galleon Leicester, under the command of Captain Edward Fenton. ${ }^{54}$ The failure of the expedition, which returned across the Atlantic without having reached the Pacific and the East Indies, "was a setback to prospects of trade with the East Indies for over a decade". ${ }^{35}$ One might expect

\footnotetext{
${ }^{50}$ Dirom Grey Crawford, $A$ history of the Indian medical service, 1600-1913, Calcutta and Simla, Thacker Spink, 1914, vol. 1. p. 2.

${ }^{31}$ RCP, Annals of the College of Physicians of London, 28 April 1587. I am indebted to Dr. C. Webster, Director of the Wellcome Unit for the History of Medicine, University of Oxford, for this reference.

'22 Hanss Jacob Wecker, A compendious chyrurgerie: gathered \& translated especially out of Wecker ... encreased and enlightened with certaine annotations, resolutions \& supplyes . . by J. Banister, London, J. Windet for J. Harrison/J. Windet for T. Man and W. Brome, 1585 (STC225185 and 25185a).

s3 John Banister, The historie of man, sucked from the sappe of the most approved anathomistes in this present age compiled in most compendious fourme, and now published in English. for the utilitie of all godly chirurgions within this realme, London, John Daye, 1578 (STC 1359).

${ }^{34}$ Keevil, op. cit., note 44 above, vol. 1, pp. 136-137. Crawford, loc. cit., note 50 above. William Noël Sainsbury (editor), Calendar of State Papers, colonial series. East Indies. 1513-1616, London, Longman Green Longman \& Roberts, 1862, pp. 72-92.

ss Alfred Leslie Rowse, The expansion of Elizabeth England, London, Cardinal edition, 1973, pp. 202-204.
} 


\section{A. L. Cooke}

that Banister, if he had been aware of Surflet's participation in Middleton's voyage, would also have been personally interested and in sympathy. As a Dudleyite, he also had the puritan's almost paranoid fear of papists, ${ }^{36}$ and probably shared Surflet's narrow religious views. Surflet, for his part, would have known of the considerable mortality on Fenton's expedition, and diligently took with him George Wateson's book, the first ever on tropical medicine and concerned with "preventing mortality incident in forraine attempts of the English nation". .7 $^{\prime}$

The cargo of pepper sent home by Middleton is significant. The English were attempting to break into the Portuguese and Dutch domination of the spice trade. The pharmaceutical aspects and possibilities of this were of interest to the physicians. Pepper was regarded as having medicinal qualities, as taught by the old authors, such as Dioscorides, Galen, Pliny, and Avicenna, and Surflet would have been aware of its reputed properties. Du Laurens discouraged its use ("Strong spices, as Ginger, Pepper, and mustard do hurt the eyes"), ${ }^{38}$ but Garcia de Orta discussed pepper from the East Indies in the work which Surflet took on his voyage, ${ }^{39}$ and Gerard, in his Herbal, wrote: "Dioscorides and others agreeing with him affirme, that Pepper resisteth poison, and is good to be put in medicaments for the eies", and "all Pepper healeth, provoketh urine, digesteth, draweth, disperseth, and clenseth the dimnesse of the sight". ${ }^{60}$ It was not long since Dr. Walter Bailey, the Regius Professor of Medicine at Oxford, had written $A$ short discourse of the three kindes of peppers in common use and certaine special medicines made of the same tending to the preservation of health, published in 1588, ${ }^{61}$ in which he set out the methods of choosing pepper and the recipes and uses of the various preparations. He was of the opinion that a better knowledge of the different types of pepper-plant (white, black, and "long") had been brought about by the "navigations in these latter yeeres made by the Portingales into the east Indians and by the Spaniards into the west Indians". ${ }^{62}$ These navigations, to the east, were now being taken up by the East India Company. By 1609, the import of pepper became, by royal proclamation, ${ }^{63}$ the monopoly of the Company.

\section{FURTHER CLUES AND CONTACTS}

The genealogical evidence as to Richard Surflet's parentage is uncertain. On the one hand, it is likely that he was closely related to the Lynn man and the former Gosberton family, ${ }^{*}$ since both men were eye-physicians. ${ }^{* *}$ On the other hand, by Elizabethan times, the principal territory of the Surflets was undoubtedly the Nottinghamshire parishes of Laxton and Weston, and the chapelry of Holme, north of

${ }^{36}$ Sainsbury, op. cit., note 54 above, p. 83.

"7 Wateson, op. cit., note 36 above, title-page. Keevil, op. cit., note 44 above, p. 119.

st $A$ discourse of the preservation of the sight, note 2 above, p. 62.

39 De Orta, op. cit., note 36 above, pp. 86-90.

${ }^{\infty} \mathrm{John}$ Gerard, The herball or generall historie of plantes, London, E. Bollifant for Bonham and John Norton. 1597 (STC 11750), p. 1357.

${ }^{61}$ Anonymously, no place, printer, or publisher named (STC 1199 and 1200).

${ }^{62}$ Ibid., fol. A 5r. Sir D'Arcy Power, 'Dr. Walter Bayley and his works, 1529-1592', Med.-chir. Trans., 1907, 90: 415-449, p. 434.

${ }^{63}$ Op. cit., note 38 above (1855), appendix, document XV.

* See note 83 below.

** See note 84 below. 


\section{Richard Surflet, translator and practitioner in physic}

Newark, ${ }^{64}$ and there are indications that Richard Surflet may have come from Holme. ${ }^{65}$ Several of those connected with the translator were from Nottinghamshire or the Newark area. We have observed Gervase Markham's interest in the Countrie farme, and he was a Nottinghamshire man. There were two ancient branches of the Markham family: one of Cotham (near Newark), the other of Sedgebrook (near Grantham), and Gervase Markham came from the Cotham branch. This Newark association of Markham, in view of his common interest with Surflet in the literature of husbandry and veterinary medicine, is striking, particularly since he was probably only a few years younger than Surflet. Markham knew the Countrie farme long before bringing out the 1616 edition. "It was a veritable mine of wealth, and he had ransacked its pages for his various previous compilations, especially The English husbandman and The English huswife." 66

Francis Herring, whose verses have been mentioned above, came from Nottinghamshire. Exactly where is not clear, but there was a Herring family at Newark. ${ }^{67}$ Walter Travers came from Nottingham, where his father was a goldsmith in Bridlesmith Gate.68 "Maister Theralde the Lynnen Draper", also mentioned in Surflet's will, was Edmund Thorold ${ }^{69}$ of Friday Street in London, probably from the ancient Lincolnshire Thorold family of Hougham and Marston, south east of Newark.

Also strongly connected with Newark was Anthony Hunton, well known as a physician there. ${ }^{70} \mathrm{He}$ was a close friend of John Banister, who himself had worked for much of the early part of his career in Nottingham. That Hunton was so close, for much of his life, to the Nottinghamshire Surflets, is remarkable, because he also had produced some medical translations, most important among them that very treatise of

\footnotetext{
44 James, op. cit., note 15 above, suggested that Richard was the son of a Richard Surflytte and Isabel Lynne, who married on 13 October 1563 at Maplebeck, near Newark, but this is rather late.

cs The translator's bequest to "some one of the sonnes of Richard Surfleete, John Surflete or Robert Surflete" is the only mention of any kinsmen in his will, and it is likely that the three men named were his cousins. They could be three of the sons of William Surflet of Laxton: Richard. Rowland, Thomas, John, Francis, and Robert, all so listed twice in their father's will, obviously in order of seniority (BIHR, will 27 March 1566, proved at York 9 May 1566). William's brother, Stephen Surflet of Holme, near Newark, a husbandman (NSDRO, will 7 July 1575, proved at Southwell 16 September 1575), left an only child, Richard, who thus had cousins Richard, John, and Robert, as set out above. This Richard (from Holme) was under twenty-one in 1575, like the Cambridge sizar (who went up the following year), and he died without issue at an unknown date. If details of his death could be established, this ought to reveal whether he was our Richard. Stephen's will provided that, if his son died without issue, certain lands were to be let and the income used by the churchwardens for the upkeep of the flood-bank at Holme. This benefaction did come into being under Stephen's will and was still operating as recently as 1934 (Nevil Truman, Holme by Newark church and its founder, Gloucester and London, British Publishing Co., 1934, p. 28). The parish records do not go back far enough to show when the charity came into operation, which, if the son was our Richard, would be 1606.

${ }^{66}$ Sir Frederick Smith, The early history of veterinary literature and its British development, London, Baillière, 1919, vol. 1, pp. 273, 277.

67 Several mentions in the indexes of York wills (Yorkshire Archaeological Society Record Series, 1891, 11; 1895, 19; 1897, 22; 1900, 28; 1902, 32).

Gnox, op. cit., note 29 above, p. 13.

6) A. M. Bruce Bannerman (ed), 'The register of St. Matthew, Friday Street, London, 1538-1812', Publications of the Harleian Society, Register section, 1933, 63: p. 13.

70 1560?-1624: Walter Jenkinson Kaye, 'Antony Hunton, M.D., an Elizabethan physician', Publications of the Thoresby Society, Miscellanea 1928, 28: 212-225.
} 


\section{A. L. Cooke}

the eyes by Jacques Guillemeau ${ }^{71}$ to which Du Laurens refers the reader of his discourse on the sight. ${ }^{72}$ Hunton's translation was published, in its second and bestknown edition, by Richard Banister in 1622, in the volume in which we have noted Richard Banister's early ophthalmic experience with Surflet of Lynn. ${ }^{16}$ The rare first edition of Hunton's translation (dedicated to John Banister) ${ }^{73}$ dating from 1587-88 was published in conjunction with two other translations by him, on scurvy and cancer, ${ }^{73}$ so, if Richard Surflet came from near Newark, a possible contact with Hunton could explain how he became interested in translating. Further, it has been reasonably suggested that it was John Banister who provided Hunton with the original French volume of Guillemeau's book used for the translation, both Banister and his colleague William Clowes being interested in encouraging translations of foreign textbooks for English medical students. ${ }^{73}$ Could Surflet also have received one or both of his French books from John Banister, directly or through Hunton?

In the case of Surflet, the provenance of the two French volumes used by him is of some further speculative interest. The court lady for whom Du Laurens's volume had been written was the brilliant and influential dowager Duchess of Uzès, whose physician he had become not long before. It was to her, the widow of the first Duke, that he dedicated it. She died in 1596, before the publication of the second edition. ${ }^{74}$ By coincidence, the French original of the Countrie farme had been dedicated by Liébault in October 1582 to the second Duke of Uzès, likewise a patient of the author (Liébault signs "Vostre plus que treshumble \& tresobeissant Medecin \& serviteur"). The first Duke had died in 1573, and the second was his brother. The dowager Duchess to whom the one book was dedicated was thus the sister-in-law of the Duke to whom the other had been. It seems hardly likely that Surflet actually came by the authors' presentation volumes from the ducal family: Liébault's dedication goes back seventeen years to his edition of 1583, and Du Laurens's dedication dates from his now-lost first edition, whilst Surflet used later editions of each book, yet the coincidence remains intriguing.

It is a pity that more is not known of Surflet's personal background, especially how, apparently from humble stock, he came to know French, Latin, and Greek, and had clearly acquired tastes of some gentility. Had he previously travelled abroad? Was there, perhaps, some continental contact through Lord Willoughby (born abroad during the Marian exile and active abroad on various occasions in his military

\footnotetext{
" Jacques Guillemeau, $A$ worthy treatise of the eyes; contayning the knowledge and cure of one hundreth and thirtene diseases, incident unto them ...., London, Robert Waldegrave for Thomas Man and William Brome, [n.d.], (STC 12499; see note 73 below).

72 "I do not set downe the remedies, which are proper to the severall diseases of the eyes, for so I should spend too much time. It was my purpose onely to prepare this generall regiment, which might serve as a patterne for the curing of all the rest. Monsieur Guillemeau the king's Surgeon, hath put forth a very learned treatise, wherein are to bee found, the most exquisite remedies set downe and used by the old and new writers. Unto his booke I referre the reader . . "” (A discourse of the preservation of the sight, note 2 above, p. 71).

${ }^{73}$ Frederick Noël Lawrence Poynter, 'Notes on a late-sixteenth-century ophthalmic work in English', The Library, 5th series, 1948, 2: 173-179. See also: Arnold Sorsby, 'A late sixteenth century ophthalmic book in English', Br. J. Ophthal., 1932, 16: 345-355, 508-509.

74 1597. The first edition appears not to have survived (Larkey, op. cit., note 2 above, pp. v-vii).

${ }^{75} \mathrm{Op}$. cit., note 7 above, fol. e $\mathrm{l}^{\mathrm{r}}$.
} 


\section{Richard Surflet, translator and practitioner in physic}

career)? ${ }^{76}$ It is difficult to believe that Surflet, hardly the type of traveller ready to forgo happily the ordinary conveniences of life, would have chosen to traverse the world in the Red Dragon if he had not already been abroad. He seems to have prided himself on his foreign contacts. His fastidious, cosmopolitan tastes extended even to the fussily intimate description of his white knitted stockings, "very thick and hayrie, bought at Cracovia by a Transilvanian Embassadour".

\section{APPENDIX}

\section{Master Surflet of Lynn}

The Sloane manuscript ${ }^{77}$ now known to be by Richard Banister ${ }^{78}$ gives some further details towards the identification of Master Surflet of Lynn: "Then ther was one Mr. Surphlete, a man of axeolente Dyet and crusty fashion of bodye. He lived till he was fouere score yeares of age, lived moste in Norfolke, \& dyed at Linn, and in good estate. He lay 2 or 3 yeares at a barber's house at Linn, to whom he taught some skille, who nowe professethe it with weake Understandinge and gyven to drinke. I cannot commende this Mr. Surphlete for any extraordinary skille, though of longe experience". ${ }^{15}$

Richard Surflet died abroad, but the Sloane manuscript explicitly states that Master Surflet of Lynn died in that town. Clearly, he was not Richard Surflet the translator. Since the Lynn man died "in good estate", one might expect him to have left a will. Searches have disclosed a solitary will, made on 31 March 1611 by "Thomas Surflett of Kinges Lynne in the county of Norff[olk], gent[leman]". Spoken on his deathbed, it does not tell us much, except, by implication, that he was not a family man. "After he had bequeathed his sowle to Almighty god and his body to Christian buriall, he gave and bequeathed unto Katherin wright of Kinges Lynn widdow all and singuler his goodes, rightes, credittes, and Chattels whatsoever in Regard of hir paynes takeing about him in his lyfe tyme and towardes the payment of his debtes and bringing his body to Christian buriall."' 79 The Freemen's roll of Lynn records that Thomas Surflet, physician, became a freeman there in 1579-80, on payment, and was admitted to the Company of Merchants on condition that he gave his services to the poor and needy when requested by the Mayor ${ }^{80} \mathrm{He}$ is again named in 1598-90, when Robert Grene, merchant, lately his apprentice, was admitted freeman. ${ }^{81}$ (Robert Greene of St Margaret's parish at Lynn, was excommunicated at

\footnotetext{
${ }^{16}$ John Woodall, for example, was at one time a military surgeon in Lord Willoughby's regiment and travelled in Germany, France, and Poland (McDonald, op. cit., note 41 above, p. 362). Richard Banister also had a connexion with the Berties: in his early career, he "wayted a yeare or twoe of ye Lord Willaby in his chamber" and was some time in Utrecht (Sorsby, op. cit., note 14 above, p. 50).

"BL, Sloane MS. 3801. Narrative transcribed in: Robert Rutson James, Studies in the history of ophthalmology in England prior to the year 1800, Cambridge University Press, 1933, pp. 53-57.

78 R. R. James and A. Sorsby, 'Richard Banister. Additional facts in relation to the Father of British Ophthalmology', Br. J. Ophthal., 1934, 18: 156-159. J. P. Hoskins and A. Sorsby, 'Richard Banister. Some further data', ibid., 1951, 35: 213-219. Sorsby, op. cit., note 14 above, pp. 50-53.

79 NfRO, Norwich Archdeaconry Court; probate granted on the day of death.

${ }^{80}$ Norfolk and Norwich Archaeological Society, A calendar of the freemen of Lynn, 1292-1836. Norwich, printed for the Society, 1913, p. 115.

s1 Ibid., p. 123. Robert Grene, surgeon deceased, is mentioned 1616-17, p. $14 i$.
} 


\section{A. L. Cooke}

Bishop Redman's visitation in 1597 , for practising surgery unlicensed. $)^{82}$ No other Surflet appears among the freemen, so this must have been the Master Surflet known to Richard Banister. He most likely came from Gosberton, near Spalding, in Lincolnshire. ${ }^{83}$ Details of his apparent kinship with the translator are unknown. ${ }^{84}$

The year after Queen Elizabeth's accession, a Thomas Surflet obtained from Cambridge University a licence to practise surgery. This was, perhaps, the man who later settled at Lynn. The licence was granted on the basis of his study and practice of surgery for "many years". ${ }^{85}$ There are notices also of a Thomas Surflet at Peterborough (the owner of some property there) between 1564 and 1577.86 Peterborough was also the home of Master Barnabie, another of the eye-practitioners under whom Richard Banister trained. ${ }^{87}$

To some extent, Richard Surflet may have built upon the Lynn man's reputation. In one of the little commendatory poems at the front of the Discourse of the preservation of the sight, Ephraim Pagit writes of Surflet's longaevae munera vitae, "the fruits of his long life" - a somewhat exaggerated phrase for a physician who can scarcely have been more than forty years of age. It would apply more aptly to Thomas Surflet, who in 1599 would have been about sixty-eight years old, and "of longe experience". No christian name is given in Pagit's poem. Could it be that the two Surflets were confused even then?

\section{SUMMARY}

Richard Surflet, the translator of $A$ discourse of the preservation of the sight . . , by André Du Laurens (1599), and the Countrie farme, by Charles Estienne and Jean Liébault (1600, 1606, 1616), was interested in medicine, ophthalmology, husbandry, veterinary medicine, and theology. He was not Master Surflet of King's Lynn, as has hitherto been suggested, and this man is identified instead as another physician, Thomas Surflet (d. 1611), about whom a little is now known. Richard Surflet's unusual will (1604) reveals more about him, his library, and his Calvinist ideas and acquaintances. Being a physician and clergyman, he was about to go, as a ship's doctor and preacher (albeit, in the event, much disliked on board), on one of the first great East Indian expeditions, upon which he perished. He may have come from near Newark and thus possibly had some contact with the agricultural and veterinary writer Gervase Markham and the physician and translator Anthony Hunton.

\footnotetext{
82 John Foster Williams (editor), 'Diocese of Norwich. Bishop Redman's visitation 1597', Norfolk Record Society, 1946, 18: p. 68. Dr. C. Webster kindly drew my attention to this mention.

${ }^{83}$ The village of Surfleet, from which the rare surname came, adjoins Gosberton, where the Surflet family is attested from the early fourteenth century (BL, MSS. Add. Ch. 21091-4; Lady Elizabeth Cust, Records of the Cust family. Second series. Brownlow family, London, Mitchell \& Hughes, 1909, pp. 339-341, 343, 345-346; LAO, will of Robert Surflet, Bishop Beaufort's register, 1400, fol. 26). Godfrey Surflet died at Grimston, Norfolk, barely six miles from King's Lynn, in 1555, leaving his lands at Gosberton to his sons Thomas and John, the latter of whom died shortly after (NfRO, will of Godfrey Surflet, Norwich Consistory Court, Walpoole fol. 276; LAO, will of John Surflet, Lincoln Consistory Court 1557 iv, fol. 221).

$\boldsymbol{\omega}^{4}$ It is strengthened by the dedication of the Countrie farme to Lord Willoughby, who was lord of the manor of Dobledyke at Gosberton (Cust, op. cit., note 83 above, p. 338). His mansion at Grimsthorpe was not far.

8s 16 June 1559. "Studium et practica multorum annorum in chirurgia", John Venn (editor), Grace Book $\Delta$, containing the records of the University of Cambridge for the years 1542-1589, Cambridge University Press, 1910, p. 135. I am indebted to Dr. C. Webster for this mention.

${ }^{26}$ William Thomas Mellows (editor), 'Peterborough local administration', Publications of the Northamptonshire Record Society, 1939, 9: pp. liii-liv, cviii, 172, 175; 1937, 10: pp. 7, 185-186, 190-191, 193-195, 200-201. W. T. Mellows and Daphne H. Gifford (editors), 'Elizabethan Peterborough', ibid., 1956, 18: pp. xlv, 58-59, 63, 67, 71, 169.

${ }^{87}$ His will (NnRO, Peterborough Consistory Court, 1600) does not mention Surflet or Banister, though otherwise of some interest.
} 